\title{
高结晶度氮掺杂介孔 $\mathrm{TiO}_{2}$ 的制备及光催化活性
}

\author{
刘二强 ${ }^{1}$, 郭晓玲 ${ }^{2}$, 秦 雷 $^{1}$, 申国栋 ${ }^{2}$, 王向东 ${ }^{1,}{ }^{*}$ \\ ${ }^{1}$ 西安交通大学理学院, 陕西西安 710049 \\ 2 西安工程大学纺织与材料学院, 陕西西安 710048
}

\begin{abstract}
摘要: 以钛酸丁酯为钛源, 尿素为氮源, 聚丙烯酰胺 (PAM) 和聚乙二醇 (PEG) 为复合模板剂, 采用溶胶-凝胶法, 在氮气和空气 气氛中分段㷽烧, 制得高结晶度氮掺杂介孔 $\mathrm{TiO}_{2}$ 光催化剂. 利用 $\mathrm{X}$ 射线衍射、透射电镜、 $\mathrm{N}_{2}$ 吸附-脱附、 $\mathrm{X}$ 射线光电子能谱和 紫外-可见漫反射光谱等技术对其进行了表征. 结果表明, 当 PAM 和 PEG 的质量比为 $1: 4$ 时, 先在氮气中 $600{ }^{\circ} \mathrm{C}$ 㷽烧, 后在空 气中 $500{ }^{\circ} \mathrm{C}$ 㷽烧所得样品是锐铁矿相, 具有良好的孔隙结构和较高的结晶度, 平均孔径为 $5.11 \mathrm{~nm}$, 晶粒尺寸为 $12.5 \mathrm{~nm}$, 比表 面积 $110.8 \mathrm{~m}^{2} / \mathrm{g}$. 掺杂介孔 $\mathrm{TiO}_{2}$ 的氮主要以取代氮和化学吸附分子 $\gamma-\mathrm{N}_{2}$ 的形式存在, 少量以间隙氮形式存在. 氮掺杂使 $\mathrm{TiO}_{2}$ 的能带变窄, 吸收带边明显红移, 且使光吸收强度显著增大. 光催化降解甲基橙实验结果表明, 与未掺杂样品相比, 氮掺杂介孔 $\mathrm{TiO}_{2}$ 在可见光作用下表现出较高的催化活性.
\end{abstract}

关键词: 介孔二氧化钛; 氮掺杂; 高结晶度; 光催化活性; 甲基橙

中图分类号: O643 文献标识码: A

收稿日期: 2012-05-06. 接受日期: 2012-07-16.

*通讯联系人. 电话: (029)82663913; 传真: (029)82663914; 电子信箱: wang90xd@hotmail.com

基金来源：国家自然科学基金 (50772082); 陕西高校省级重点实验室科研项目 (2010JS007).

本文的英文电子版(国际版)由Elsevier出版社在ScienceDirect上出版(http://www.sciencedirect.com/science/journal/18722067).

\section{Fabrication and Photocatalytic Activity of Highly Crystalline Nitrogen Doped Mesoporous $\mathrm{TiO}_{2}$}

\author{
LIU Erqiang ${ }^{1}$, GUO Xiaoling ${ }^{2}$, QIN Lei ${ }^{1}$, SHEN Guodong ${ }^{2}$, WANG Xiangdong ${ }^{1, *}$ \\ ${ }^{1}$ School of Science, Xi'an Jiaotong University, Xi'an 710049, Shaanxi, China \\ ${ }^{2}$ School of Textile and Materials, Xi'an Polytechnic University, Xi'an 710048, Shaanxi, China
}

\begin{abstract}
Highly crystalline nitrogen doped mesoporous $\mathrm{TiO}_{2}$ photocatalysts were fabricated by the sol-gel method using tetrabutyl titanate as the Ti source, urea as the $\mathrm{N}$ source, and polyacrylamide (PAM) and polyethylene glycol (PEG) as the templates, and then by calcining in nitrogen and air. The photocatalysts were characterized by X-ray diffraction, transmission electron microscopy, $\mathrm{N}_{2}$ adsorption, $\mathrm{X}$-ray photoelectron spectroscopy, and UV-Vis spectroscopy. When the mass ratio of PAM and PEG was 1:4, the sample prepared by calcining at $600{ }^{\circ} \mathrm{C}$ in nitrogen and $500{ }^{\circ} \mathrm{C}$ in air had the anatase phase and a mesoporous structure and high crystallinity. The average pore size, crystallite size, and specific surface area were $5.11 \mathrm{~nm}, 12.5 \mathrm{~nm}$, and $110.8 \mathrm{~m}^{2} / \mathrm{g}$, respectively. Nitrogen atoms were incorporated into the $\mathrm{TiO}_{2}$ lattice mainly as substitutional $\mathrm{N}$ and molecularly chemisorbed $\gamma-\mathrm{N}_{2}$, and a small amount of interstitial $\mathrm{N}$. Nitrogen doping narrowed the band gap and allowed light absorption in the visible light region. Compared with undoped mesoporous $\mathrm{TiO}_{2}$, the absorption band edge of nitrogen doped samples exhibited a red shift and the light absorption intensity was increased. Photocatalytic degradation of methyl orange showed that the nitrogen doped mesoporous $\mathrm{TiO}_{2}$ had a higher photocatalytic activity than undoped mesoporous $\mathrm{TiO}_{2}$ under visible light.
\end{abstract}

Key words: mesoporous titanium dioxide; nitrogen doped; high crystallinity; photocatalytic activity; methyl orange 
Mesoporous $\mathrm{TiO}_{2}$ is well studied because of its photocatalytic activity, which is used in photoelectrochemical applications [1-7]. Mesoporous $\mathrm{TiO}_{2}$ prepared by traditional methods still has some disadvantages such as low crystallinity, low thermostability, and low visible light response. Mesoporous $\mathrm{TiO}_{2}$ with enhanced crystallinity and thermostability is required in many demanding applications, such as solar energy conversion, batteries, and photocatalysis, because the semiconducting and photovoltaic behavior is largely dependent on the crystallinity of the $\mathrm{TiO}_{2}$. Many approaches have been taken to improve the crystallinity of mesoporous $\mathrm{TiO}_{2}$, including using several block copolymers as templates to give a much thicker pore wall composed of nanocrystals embedded in an amorphous material [8-10]. When these materials are converted into the completely crystalline state at high temperature, the mesoporous structure collapses due to the growth of the nanocrystals. Despite much effort, it is a major challenge to successfully convert the amorphous walls of mesoporous $\mathrm{TiO}_{2}$ to crystalline walls while retaining the original mesoporous structure.

To solve the above problem, Lee et al. [11] reported a new method in which an amphiphilic diblock copolymer, poly(isoprene-block-ethylene oxide), was used as the template to synthesize mesoporous $\mathrm{TiO}_{2}$, which was then calcined in an Ar atmosphere first and then recalcined in air. The mesoporous $\mathrm{TiO}_{2}$ prepared by this method has high crystallinity, high thermostability, and high surface area. However, the disadvantage of the method is the cost of the template. Their study did not report about $\mathrm{TiO}_{2}$ doping especially with nonmetal elements such as $\mathrm{N}$ [12-15], F $[16,17], \mathrm{S}[18]$, and C [19,20], which can create a mid-gap state that acts as electron donor or acceptor in the band gap of $\mathrm{TiO}_{2}$. The doping can narrow the band gap of $\mathrm{TiO}_{2}$ and extend its light absorption into the visible region, which would then enhance the quantum efficiency of the material, improving its photocatalytic activity under visible light.

In the present paper, we report a sol-gel method using polyacrylamide (PAM) and polyethylene glycol (PEG) as templates to synthesis nitrogen doped mesoporous $\mathrm{TiO}_{2}$ with high surface area and high crystallinity. The materials were characterized by X-ray diffraction (XRD), transmission electron microscopy (TEM), $\mathrm{N}_{2}$ adsorption, X-ray photoelectron spectroscopy, and UV-Vis spectroscopy. The photocatalytic activities of the undoped and nitrogen doped mesoporous $\mathrm{TiO}_{2}$ were evaluated by the photocatalytic degradation of methyl orange (MO) in water.

\section{Experimental}

\subsection{Photocatalyst synthesis}

The sol-gel preparation of the nitrogen doped mesopor- ous $\mathrm{TiO}_{2}$ was performed as follows. Deionized water (10 $\mathrm{ml})$, nitric acid $(5 \mathrm{wt} \%, 6 \mathrm{ml})$, and $0.5-6.0 \mathrm{~g}$ of urea dissolved in $280 \mathrm{ml}$ of absolute ethanol were added into $10 \mathrm{ml}$ of tetrabutyl titanate. After the mixture was stirred at ambient temperature for $1 \mathrm{~h}$, the resulting solution was slowly added into a solution of $0.2 \mathrm{~g}$ PAM $(\mathrm{Wt}=3000000)$ and 0.8 g PEG $(\mathrm{Wt}=20000)$ dissolved in $30 \mathrm{ml}$ of deionized water under vigorously stirring. A white gel was formed, which was dried at $60{ }^{\circ} \mathrm{C}$ for $12 \mathrm{~h}$. The light yellow powder obtained was calcined in a $\mathrm{N}_{2}$ atmosphere and $400-800{ }^{\circ} \mathrm{C}$, and then recalcined in air at $400-700{ }^{\circ} \mathrm{C}$. For comparison, undoped mesoporous $\mathrm{TiO}_{2}$ was prepared according to the above procedure with the absence of urea.

\subsection{Photocatalyst characterization}

XRD patterns of the photocatalysts were recorded at room temperature by a Bruker D8 Advance X-ray diffractometer using $\mathrm{Cu} K_{\alpha}$ radiation and a scan rate of $2 \% \mathrm{~min}$. TEM image was recorded on a JEM-2100F made in Japan. $\mathrm{N}_{2}$ adsorption isotherms were collected on an AUTOSORB-1 nitrogen adsorption apparatus at $-196{ }^{\circ} \mathrm{C}$. XPS analysis was performed using a PHI 5300 ESCA instrument with an $\mathrm{Mg} K_{\alpha}$ X-ray source at a power of $250 \mathrm{~W}$. The binding energy was calibrated with respect to the $\mathrm{C} 1 \mathrm{~s}$ peak of hydrocarbon contamination at $284.6 \mathrm{eV}$. Diffuse reflectance UV-visible absorption spectra of the powder samples were obtained using a Shimadzu-2501 spectrophotometer. $\mathrm{BaSO}_{4}$ was the reference sample, and the spectra were recorded in the range of 200-900 $\mathrm{nm}$.

\subsection{Photocatalytic activity}

Photocatalytic activity was tested by the photocatalytic degradation of MO solutions under visible light irradiation at room temperature. The reactor was a $100 \mathrm{ml}$ cylindrical vessel containing $60 \mathrm{ml}$ of MO solution with a water-cooled quartz jacket. Irradiation was by a $300 \mathrm{~W}$ xenon lamp located in the center of the quartz jacket, which emitted a similar spectrum to visible light. This was equipped with a magnetic stirrer at the bottom of the reactor to achieve effective dispersion. The initial MO concentration was 10 $\mathrm{mg} / \mathrm{L}$ and the amount of photocatalyst was $150 \mathrm{mg}$. Before irradiation, $30 \mathrm{~min}$ adsorption was allowed to reach adsorption equilibrium with the photocatalyst and MO solutions were kept in a dark condition. Then the mixed solution was irradiated. The solution $(4 \mathrm{ml})$ was taken out at regular intervals and separated by centrifugal separation to determine the residual concentration of MO by a spectrophotometer (UV-7220, Beifenruili, China) at $464 \mathrm{~nm}$. The change of relative absorbance was used to record the change of concentration of $\mathrm{MO}$ in the solution. 


\section{Results and discussion}

\subsection{Photocatalyst synthesis}

Figure 1 shows the synthesis mechanism of the photocatalysts. The nitrogen doped mesoporous $\mathrm{TiO}_{2}$ was prepared by two steps. First, a sol-gel process was conducted using tetrabutyl titanate as the $\mathrm{Ti}$ source, urea as the $\mathrm{N}$ source, and PAM and PEG as the templates. Due to its strong hydrophilicity, PEG readily combined with the titania sol obtained from the hydrolyzation to form composite grains. These composite grains were incorporated in PAM by hydrogen bonding, and the grains were confined in the molecule network of PAM. This bonding process can effectively accelerate the sol-gel reaction. Second, the precursor prepared by the sol-gel process was successively calcined in a $\mathrm{N}_{2}$ atmosphere and air atmosphere to synthesize the photocatalyst. Nitrogen doped mesoporous $\mathrm{TiO}_{2}$ with a high crystallinity and high surface area was obtained. This was because in this method, PEG was easily decomposed on heating, whereas the more thermally stable PAM was converted to a sturdy, amorphous carbon when calcined in $\mathrm{N}_{2}$. The amorphous carbon acted as a rigid support of the mesoporous structure that prevented its collapse when it was calcined to the temperature required for getting a highly crystalline material [11]. The carbon was subsequently eliminated by calcining in air, leaving a highly crystalline mesoporous material.

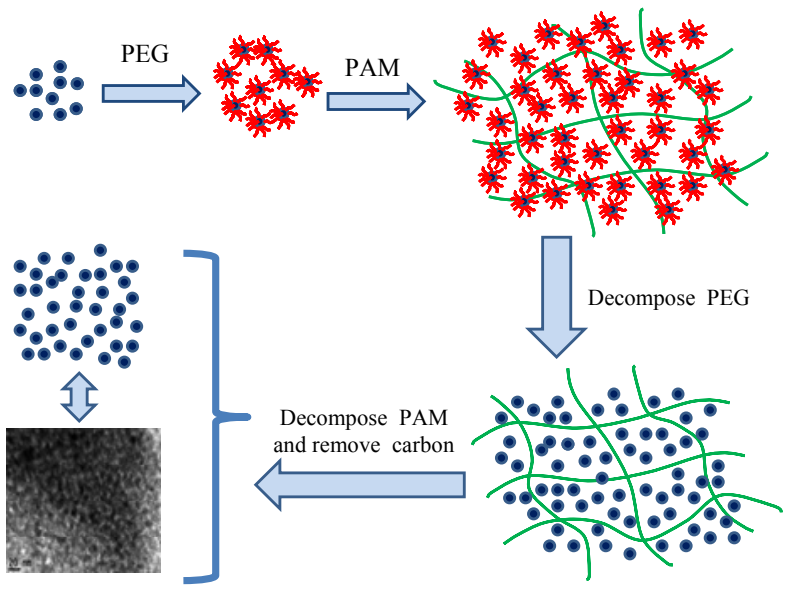

Fig. 1. Illustration of the synthesis mechanism of the photocatalysts.

\subsection{XRD analysis}

Figure 2 shows the XRD patterns of the nitrogen doped mesoporous $\mathrm{TiO}_{2}$ prepared with the PAM:PEG mass ratio 1:4 after calcination at different temperatures. The phase composition of the samples was mainly anatase and an amorphous phase when the calcining temperature was low (Figs. 2(1) and (2)). The rutile phase appeared when the

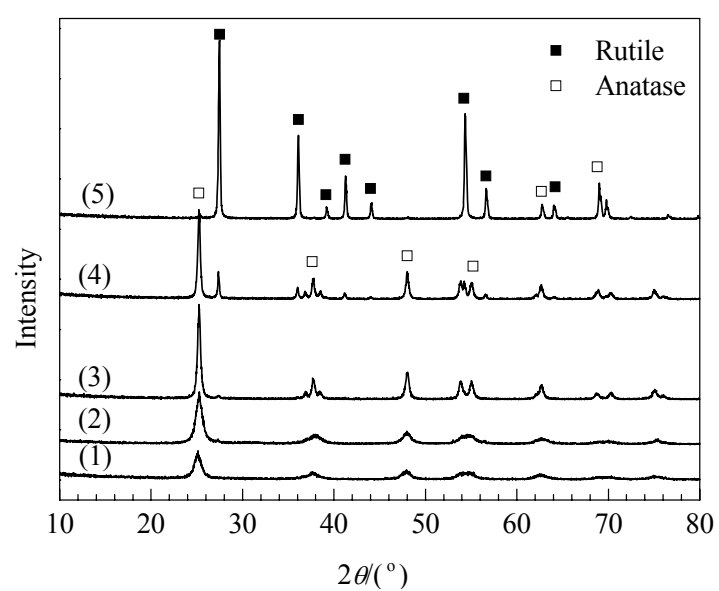

Fig. 2. XRD patterns of samples calcined at different temperatures ( $\mathrm{N}_{2} /$ air). (1) $400 / 400{ }^{\circ} \mathrm{C}$; (2) $500 / 400{ }^{\circ} \mathrm{C}$; (3) $600 / 500{ }^{\circ} \mathrm{C}$; (4) $700 / 600$ ${ }^{\circ} \mathrm{C}$; (5) $800 / 700{ }^{\circ} \mathrm{C}$.

calcining temperature was $700 / 600{ }^{\circ} \mathrm{C}$ (Fig. 2(4)), and it was the main phase when the temperature was $800 / 700{ }^{\circ} \mathrm{C}$ (Fig. 2(5)). It was a good calcining temperature $(600 / 500$ ${ }^{\circ} \mathrm{C}$, Fig. 2(3)) because the phase composition of the sample was mainly anatase and it has a high specific surface areas (Table 1). The diffraction peak became significantly sharper with the increase in calcining temperature, indicating an increase in crystallinity $[13,21]$. The average crystallite size of the anatase crystals, estimated from the X-ray peak width using the Scherrer equation, became larger with the increase of the calcining temperature (Table 1). The specific surface area decreased sharply with the increase in calcining temperature. So, in this method, the calcining temperature of 600 (in $\mathrm{N}_{2}$ ) and $500{ }^{\circ} \mathrm{C}$ (in air) were appropriate to optimize the crystallinity, crystal phase, and specific surface area.

Table 1 Characterization results of samples prepared at different temperatures

\begin{tabular}{|c|c|c|c|c|}
\hline \multicolumn{2}{|c|}{$T /{ }^{\circ} \mathrm{C}$} & \multirow{2}{*}{$\begin{array}{l}A_{\mathrm{BET}} / \\
\mathrm{m}^{2} / \mathrm{g}\end{array}$} & \multirow{2}{*}{ Phase } & \multirow{2}{*}{$\begin{array}{c}\text { Crystallite size } \\
(\mathrm{nm})\end{array}$} \\
\hline $\mathrm{N}_{2}$ & air & & & \\
\hline 400 & 400 & 171.2 & A + Amors & 9.45 \\
\hline 500 & 400 & 135.2 & $\mathrm{~A}+$ Amors. & 9.36 \\
\hline 600 & 500 & 110.8 & A & 12.46 \\
\hline 700 & 600 & 42.3 & A & 21.35 \\
\hline 800 & 700 & 19.8 & $A+R$ & $25.47+41.38$ \\
\hline
\end{tabular}

A: anatase phase; R: rutile phase; Amors: amorphous phase.

\subsection{TEM analysis}

Figure 3 shows the TEM images of the sample prepared at the calcination temperature of $600 / 500{ }^{\circ} \mathrm{C}$. It can be seen from Fig. 3(a) that the sample has a typical honeycomb porous structure with high crystallinity, in which the agglomeration of monodispersed $\mathrm{TiO}_{2}$ particles was clearly ob- 


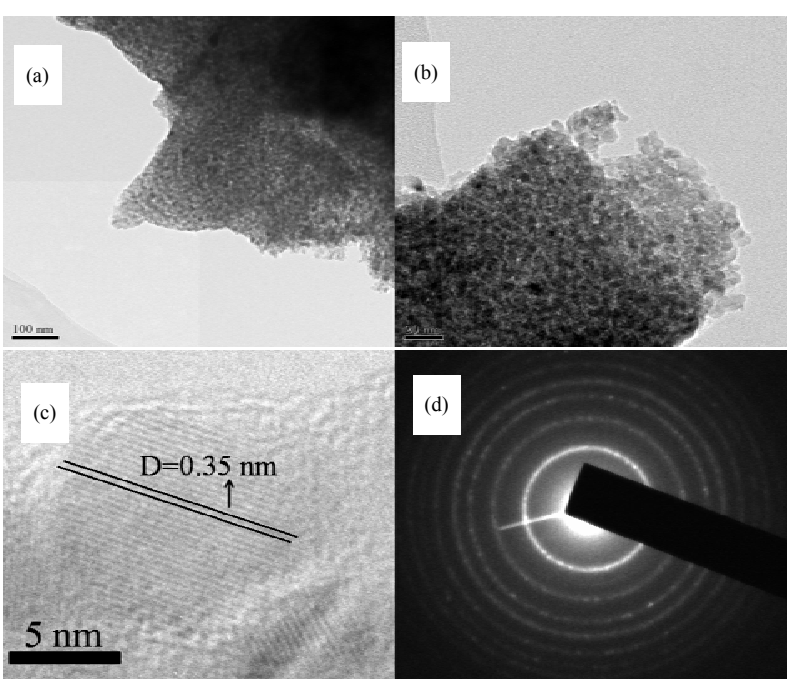

Fig. 3. Samples characterized by TEM. (a,b) TEM images; (c) HRTEM image; (d) SAED pattern.

served. Figure 3(b) shows that the sample has a wormhole-like pore structure. The pores were connected randomly and lack a discernible long range order in the pore arrangement. Anatase $\mathrm{TiO}_{2}$ nanocrystals were embedded in the disordered mesoporous framework. As seen in Fig. 3(c), the lattice fringe measured in the HRTEM image had an

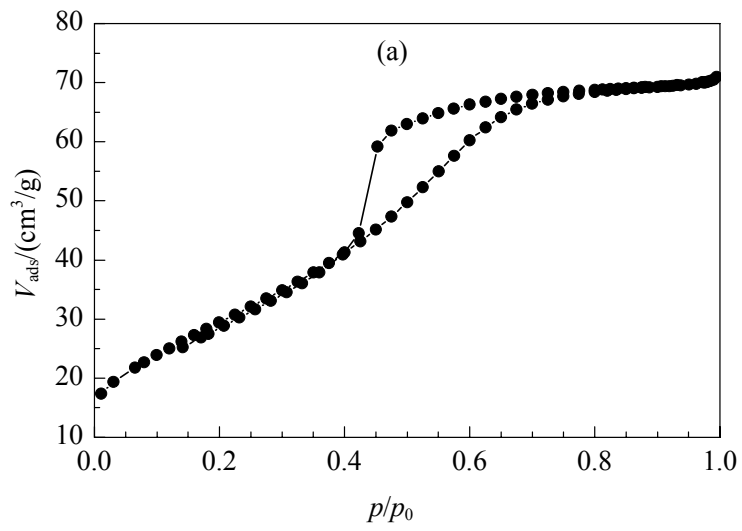

average interplanar spacing of $0.35 \mathrm{~nm}$, which is that of $\mathrm{TiO}_{2}$ (d101) in the corresponding wide angle XRD pattern [22-24]. The pore size and grain size were, respectively, 5-7 nm and 12-14 nm, which were in good agreement with the $\mathrm{N}_{2}$ adsorption and XRD results. The selected area electron diffraction (SAED) pattern of the sample (Fig. 3(d)) showed a sequence of diffraction rings consistent with those expected of anatase $\mathrm{TiO}_{2}[11,25]$.

\section{$2.4 \quad \mathrm{~N}_{2}$ adsorption}

Figure 4 shows the $\mathrm{N}_{2}$ adsorption isotherm and pore size distribution curve of the sample prepared at the calcining temperature of $600 / 500{ }^{\circ} \mathrm{C}$. The specific surface area calculated from the linear part of the adsorption isotherm was $110.8 \mathrm{~m}^{2} / \mathrm{g}$. The $\mathrm{N}_{2}$ adsorption-desorption isotherm was Type IV with a $\mathrm{H}_{2}$ hysteresis, which is typical of mesoporous materials [26,27]. The average mesopore size estimated using the Barrett-Joyner-Halenda (BJH) approach from the desorption branch was $5.11 \mathrm{~nm}$ (Fig. 4(b)), which was in agreement with the pore size estimated from TEM images (Fig. 3). From the crystallite size of the sample, the mesopores were probably formed by the agglomeration and connection of adjacent nanoparticles in the sample, which were seen in the TEM results (Figs. 3(a) and (b)).

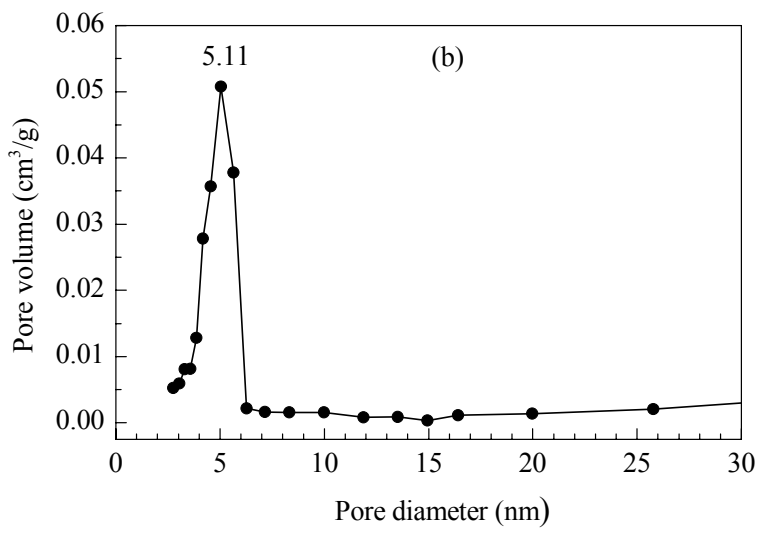

Fig. 4. $\mathrm{N}_{2}$ adsorption isotherm (a) and pore size distribution (b) for the sample prepared at the calcining temperature of $600 / 500{ }^{\circ} \mathrm{C}$.

\subsection{XPS analysis}

Figure 5 shows the XPS spectra of the nitrogen doped mesoporous $\mathrm{TiO}_{2}$ sample prepared with the calcining temperature of $600 / 500{ }^{\circ} \mathrm{C}$ and mole proportion of urea and tetrabutyl titanate of 2:1. Obvious peaks of titanium, oxygen, nitrogen, and carbon were detected in Fig. 5(a). The binding energies of Ti $2 p, \mathrm{O} 1 s, \mathrm{~N} 1 s$, and $\mathrm{C} 1 s$ were 458.5, 531, 400, and $284 \mathrm{eV}$, respectively, which was approximately in agreement with the data of other researchers [28-30]. The carbon signal was from the residual carbon from the precursor solution and adventitious hydrocarbon in the XPS instrument itself. The total nitrogen concentration, estimated from the XPS data, was $0.6 \%$ (molar ratio of elements).

Figure 5(b) shows the high resolution XPS spectra of the $\mathrm{N} 1 s$ region. Three XPS peaks at 397.0, 398.8, and $402.4 \mathrm{eV}$ were observed. Different N $1 s$ peak positions represent various forms of nitrogen in doped $\mathrm{TiO}_{2}$. In most cases, the peak at $397.0 \mathrm{eV}$ was ascribed to the $\mathrm{Ti}-\mathrm{N}-\mathrm{Ti}$ bond indicating that nitrogen atom was substitutionally doped into the $\mathrm{TiO}_{2}$ lattice [31-33]. The peak at $400 \mathrm{eV}$ is related to oxidized nitrogen such as Ti-O-N or Ti-N-O bonding, so the peak at $398.8 \mathrm{eV}$ can be attributed to anionic $\mathrm{N}^{-}$in interstitial $\mathrm{N}$ $[31,32,34]$. The peak at $402.4 \mathrm{eV}$ was observed and attrib- 

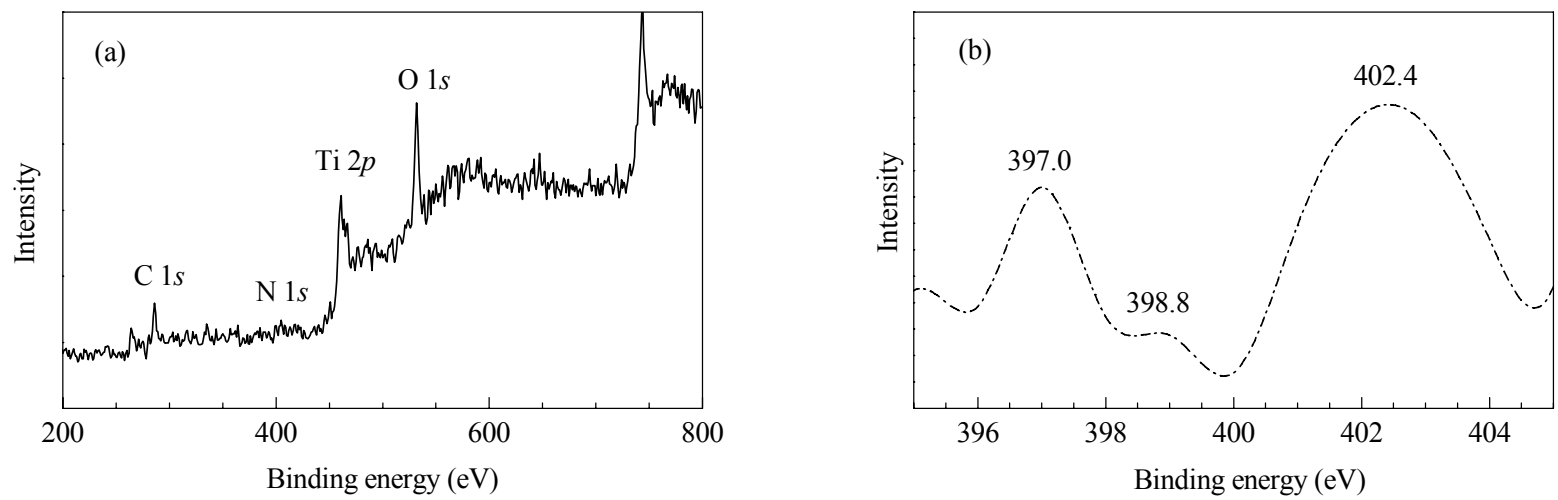

Fig. 5. XPS spectra (a) and high resolution XPS spectra of $\mathrm{N} 1 s$ (b) for the nitrogen doped mesoporous $\mathrm{TiO}_{2}$.

uted to molecularly chemisorbed $\gamma-\mathrm{N}_{2}$, in which $\mathrm{N}$ atoms were incorporated into the $\mathrm{TiO}_{2}$ lattice as $\mathrm{N}_{2}$ molecules [12,35]. In Fig. 5(b), the peaks at 402.4 and $397.0 \mathrm{eV}$ have a higher intensity than the peak at $398.8 \mathrm{eV}$. From the XPS results, it was concluded that the forms of doped nitrogen incorporated into the $\mathrm{TiO}_{2}$ lattice were mainly substitutional $\mathrm{N}$ and molecularly chemisorbed $\gamma-\mathrm{N}_{2}$ molecules, with some interstitial N. According to the literature [31,36,37], interstitial nitrogen doping is favored with oxygen-rich and low calcining temperature conditions, while substitutional nitrogen doping is preferred with the absence of oxygen and high calcining temperature conditions. In the present work, the first calcining was performed in $\mathrm{N}_{2}$, which is an oxygen-deficient condition, and at a high calcining temperature $\left(600{ }^{\circ} \mathrm{C}\right)$, so the nitrogen atoms were mainly incorporated into substitutional sites.

\subsection{UV-Vis DRS spectra}

Figure 6 shows the UV-Vis diffuse reflectance spectra of undoped and nitrogen doped mesoporous $\mathrm{TiO}_{2}$ photocatalysts prepared with different mole ratios of urea and

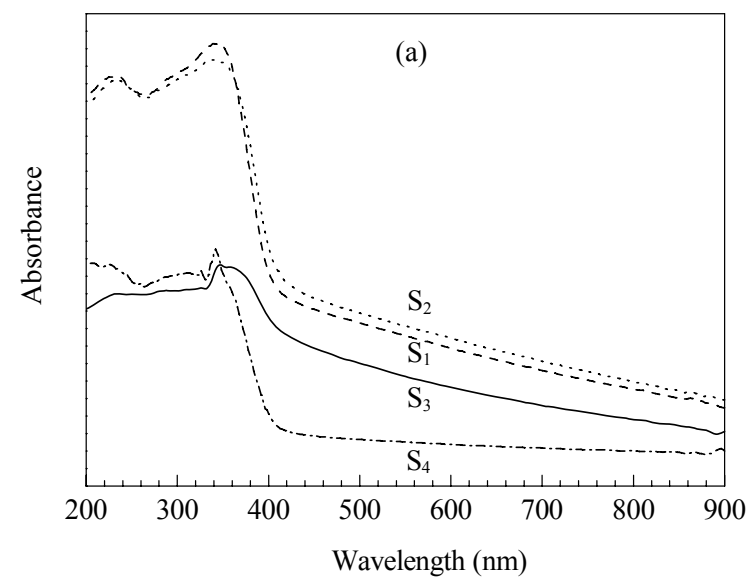

tetrabutyl titanate and at the calcining temperature of $600 / 500{ }^{\circ} \mathrm{C}$. All the absorption band edges of the nitrogen doped mesoporous $\mathrm{TiO}_{2}$ samples exhibited an evident red shift, and the light absorption intensity of the nitrogen doped samples was higher than that with undoped $\mathrm{TiO}_{2}\left(\mathrm{~S}_{4}\right)$. As seen in Fig. 6(a), pure anatase $\mathrm{TiO}_{2}$ showed absorption peaks at $400 \mathrm{~nm}$. This may be because in the present work, the pure anatase $\mathrm{TiO}_{2}$ was prepared in a $\mathrm{N}_{2}$ atmosphere and high temperature and has oxygen vacancies, which contributed to the absorption red shift of oxygen-deficient $\mathrm{TiO}_{2}$ [38]. With the increase of the mole ratio of urea and tetrabutyl titanate, the absorption intensity of visible light of the nitrogen doped samples increased. When the mole ratio of urea and tetrabutyl titanate was 2:1 $\left(\mathrm{S}_{1}\right)$, the absorption intensity of visible light was the highest. That is, absorption intensity increased with increasing nitrogen doping concentration. The light absorbance enhancement in the UV-visible light range was consistent with the yellow color of the sample. The enhanced light absorption in the visible range of the nitrogen doped samples was because nitrogen doping significantly shifted light absorption to the visible region through band gap narrowing [36-39].

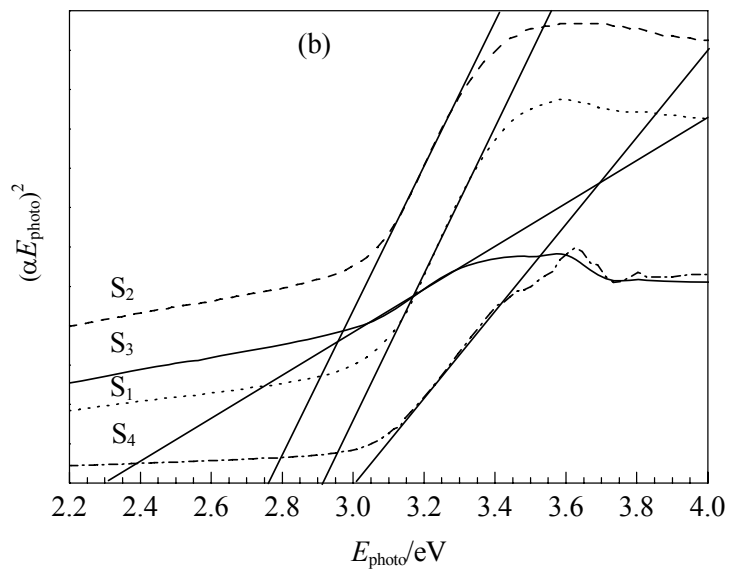

Fig. 6. UV-Vis DRS spectra (a) and band gap from the plots of $\left(\alpha E_{\text {photon }}\right)^{2}$ vs energy of absorbed light (b) of samples prepared with different mole ratios of urea and tetrabutyl titanate. $\mathrm{S}_{1}: \mathrm{CO}\left(\mathrm{NH}_{2}\right)_{2}: \mathrm{TiO}_{2}=2: 1 ; \mathrm{S}_{2}: \mathrm{CO}\left(\mathrm{NH}_{2}\right)_{2}: \mathrm{TiO}_{2}=1: 1 ; \mathrm{S}_{3}: \mathrm{CO}\left(\mathrm{NH}_{2}\right)_{2}: \mathrm{TiO}_{2}=1: 2 ; \mathrm{S}_{4}: \mathrm{TiO}_{2}$. 
Figure 6(b) shows the absorption edge of the samples. The plots of $\left(\alpha E_{\text {photon }}\right)^{2}$ versus energy of absorbed light gave the band gap of the samples [32,40,41]. The band gap energies were measured to be $2.3-2.9 \mathrm{eV}$ for the samples prepared with various mole proportion of urea and tetrabutyl titanate. The narrowed band gap was due to the contributions of the nitrogen dopant and oxygen vacancies in the $\mathrm{TiO}_{2}$ lattice. The nitrogen dopant induced local states above the valence band edge and oxygen vacancies gave rise to mid-gap states below the conduction band [31,33,34,42]. These were responsible for the photocatalytic degradation reaction under visible light irradiation. $\mathrm{S}_{3}$ has the lowest band gap energy, but its absorption intensity was also the lowest. So, taking into account band gap energy and absorption intensity, $\mathrm{S}_{2}$ was the best sample.

\subsection{Photocatalytic activity}

The photocatalytic activity of the samples was measured by the degradation of MO solutions under visible light irradiation at room temperature. Figure 7 shows the degradation kinetics of the MO solutions. A blank test indicated that in the absence of a photocatalyst, decoloration of the MO solution was negligible. Compared with undoped mesoporous $\mathrm{TiO}_{2}$, the nitrogen doped mesoporous $\mathrm{TiO}_{2}$ photocatalysts showed obviously promoted photocatalytic activity. The degradation rates of all the nitrogen doped mesoporous $\mathrm{TiO}_{2}$ photocatalysts were more than $60 \%$ for $12 \mathrm{~h}$ of irradiation time, while it was below $20 \%$ for undoped mesoporous $\mathrm{TiO}_{2}$. The higher photocatalytic activity of the nitrogen doped $\mathrm{TiO}_{2}$ photocatalysts under visible light irradiation was explained by the following. Nitrogen doping resulted in the shift of the absorbance of light towards longer wavelength. As shown in Fig. 6, the nitrogen doped mesoporous $\mathrm{TiO}_{2}$ exhibited strong absorption in the visible light region,

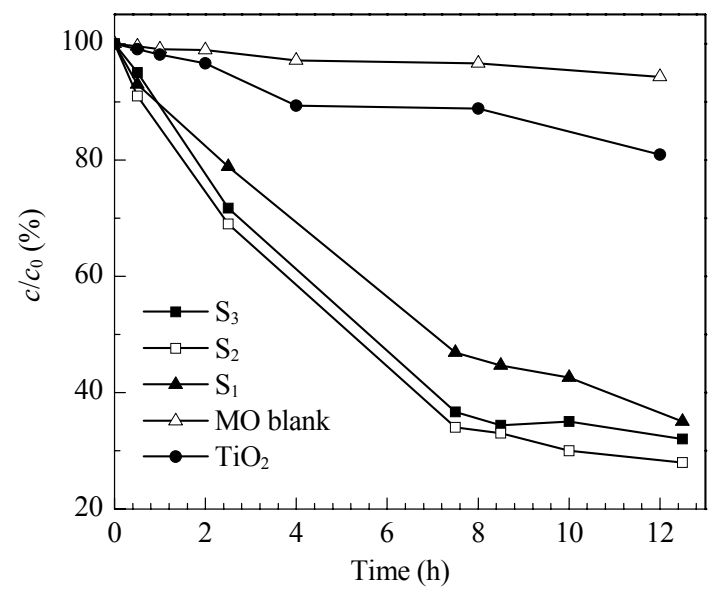

Fig. 7. Photocatalytic degradation kinetics of MO solutions under visible light irradiation. while the undoped mesoporous $\mathrm{TiO}_{2}$ absorbed only in the UV region. From Fig. 7, the photocatalytic activity sequence of the nitrogen doped mesoporous $\mathrm{TiO}_{2}$ photocatalysts was $\mathrm{S}_{2}>\mathrm{S}_{3}>\mathrm{S}_{1}$. The sequence of the mole ratios of urea and tetrabutyl titanate of the three samples was $\mathrm{S}_{1}>\mathrm{S}_{2}$ $>\mathrm{S}_{3}$. This result indicated that with an appropriate amount of nitrogen doping, photoexcited electrons and holes can be separated efficiently and the photocatalytic activity was enhanced, but excessive nitrogen doping may act as the recombination centers for photoexcited electrons and holes, which reduces the photocatalytic activity [43]. The photocatalytic activity of the nitrogen doped mesoporous $\mathrm{TiO}_{2}$ samples was in agreement with their UV-Vis diffuse reflectance spectra.

\section{Conclusions}

Nitrogen doped mesoporous $\mathrm{TiO}_{2}$ with high crystallinity and a large specific surface area was fabricated using a sol-gel method in which PAM and PEG were used as templates. When calcined in $\mathrm{N}_{2}$, PAM was converted into a sturdy, and the amorphous carbon that prevented the collapse of the mesoporous structure when the sample was calcined to the temperature required for getting high crystallinity. When the mass ratio of PAM and PEG was 1:4, the sample prepared at $600{ }^{\circ} \mathrm{C}$ in nitrogen and at $500{ }^{\circ} \mathrm{C}$ in air has the anatase phase, and it has a mesoporous structure with high crystallinity and a high specific surface area. The absorption band edges of the nitrogen doped mesoporous $\mathrm{TiO}_{2}$ samples exhibited a red shift and their absorption intensity was higher than that of the undoped sample, that is, nitrogen doping made the band gap of $\mathrm{TiO}_{2}$ narrower. Compared with the undoped sample, nitrogen doped mesoporous $\mathrm{TiO}_{2}$ has a higher photocatalytic activity under irradiation of visible light.

\section{References}

1 Wu C W, Ohsuna T, Kuwabara M, Kuroda K. J Am Chem Soc, 2006, 128: 4544

2 Wan Y, Yang H F, Zhao D Y. Acc Chem Res, 2006, 39: 423

3 Hao H Y, Zhang J L. Microporous Mesoporous Mater, 2009, 121: 52

4 向全军, 余家国. 催化学报 (Xiang Q J, Yu J G. Chin J Catal), 2011, 32: 525

5 Bleta B, Alphonse P, Lorenzato L. J Phys Chem C, 2010, 114: 2039

6 Liu Y J, Szeifert J M, Feck J M, Mandmeier B, Rathousky J, Hayden O, Fattakhova-Rohlfing P, Bein T. ACS Nano, 2010, 4: 5373

7 Liu S W, Yu J G, Jaroniec M. Chem Mater, 2011, 23: 4085

8 Kim D S, Kwak S Y. Appl Catal A, 2007, 323: 110 
9 Serrano D P, Calleja G, Sanz R, Pizarro P. J Mater Chem, 2007, 17: 1178

10 Liang G, Xu J, Xu W, Shen X, Zhang H, Yao M. J Optoelectron Adv Mater, 2010, 12: 1758

11 Lee J, Oriall M C, Warren S C, Kamperman M, Disalvo F J, Wiesner U. Nature Mater, 2008, 7: 222

12 Asahi R, Morikawa T, Ohwaki T, Aoki K, Taga Y. Science, 2001, 293: 269

13 Liu G, Yang H G, Wang X W, Cheng L N, Pan J, Lu G Q, Cheng H M. J Am Chem Soc, 2009, 131: 12868

14 Cong Y, Zhang J L, Chen F, Anpo M, He D N. J Phys Chem C, 2007, 111: 10618

15 Yang K S, Dai Y, Huang B B, Whangbo M H. J Phys Chem C, 2009, 113: 2624

16 Pan J H, Zhang X W, Du A J, Sun D D, Leckie J O. J Am Chem Soc, 2008, 130: 11256

17 Liu S W, Yu J G, Cheng B, Jaroniec M. Adv Colloid Interface Sci, 2012, 173: 35

18 Periyat P, Mccormack D E, Hinder S J, Pillai S C. J Phys Chem C, 2009, 113: 3246

19 Xu P, Lu J, Xu T, Gao S M, Huang B B, Dai Y. J Phys Chem C, 2010, 114: 9510

20 Wang D H, Jia L, Wu X L, Lu L Q, Xu A W. Nanoscale, 2012, 4: 576

21 Tian G H, Fu H G, Jing L Q, Xin B F, Pan K. J Phys Chem C, 2008, 112: 3083

22 Ren W J, Ai Z H, Jia F L, Zhang L Z, Fan X X, Zou Z G. Appl Catal B, 2007, 69: 138

23 Zhang Y, Li J, Wang J. Chem Mater, 2006, 18: 2917

24 Xu X M, Li X N, Lin P Y, Chen T, Yuan R S, Ding Z X, Wu L, Wang X X, Li Z H. Chem Commun, 2011, 47: 2538

25 Wang D H, Ma Z, Dai S, Liu J, Nie Z M, Engelhard M H, Huo Q S, Wang C M, Kou R. J Phys Chem C, 2008, 112: 13499

26 Yu J C, Zhang L Z, Yu J G. Chem Mater, 2002, 14: 4647
27 Wang X J, Hu D D, Yang J X. Chem Mater, 2007, 19: 2610

28 Irie H, Watanabe Y, Hashimoto K. J Phys Chem B, 2003, 107: 5483

29 Choi H, Antoniou M G, Pelaez M, Dela Cruz A A, Shoemaker J A, Dionysiou D D. Environ Sci Technol, 2007, 41: 7530

30 Shieh D L, Lin Y S, Yeh J H, Chen S C, Lin B C, Lin J L. Chem Commun, 2012, 48: 2528

31 Wang J, Tafen D N, Lewis J P, Hong Z L, Manivannan A, Zhi M J, Wu N Q. J Am Chem Soc, 2009, 131: 12290

32 Mitoraj D, Kisch H. Angew Chem, Int Ed, 2008, 47: 9975

33 Etacheri V, Seery M K, Hinder S J, Pillai. Chem Mater, 2010, 22: 3843

34 Yang G D, Jiang Z, Shi H H, Xiao T C, Yan Z F. J Mater Chem, 2010, 20: 5301

35 Morikawa T, Asahi R, Ohwaki T, Aoki K, Taga Y. Jpn J Appl Phys, 2001, 40: 561

36 Xiang Q J, Yu J G, Jaroniec M. Phys Chem Chem Phys, 2011, 13: 4853

37 Xiang Q J, Yu J G, Wang W G, Jaroniec M. Chem Commun, 2011, 47: 6906

38 Lin Z, Orlov A, Lambert R M, Payne M C. J Phys Chem B, 2005, 109: 20948

39 Spadavecchia, F, Cappelletti G, Ardizzone S, Bianchi C L, Cappelli S, Oliva C, Scardi P, Leoni M, Fermo P. Appl Catal $B, 2010,96: 314$

40 Wu G S, Nishikawa T, Ohtani B, Chen A C. Chem Mater, 2007, 19: 4530

41 Zabek P, Eberl J, Kisch H. Photochem Photobiol Sci, 2009, 8: 264

42 Fujishima A, Zhang X T, Tryk D A. Surface Science Reports, 2008, 63: 515

43 张晓茹, 林艳红, 张健夫, 何冬青, 王德军. 物理化学学报 (Zhang X R, Lin Y H, Zhang J F, He D Q, Wang D J. Acta Phys-Chim Sin), 2010, 26: 2733 